\title{
Hepatocyte Nuclear Factor 3-Gamma
}

National Cancer Institute

\section{Source}

National Cancer Institute. Hepatocyte Nuclear Factor 3-Gamma. NCI Thesaurus. Code C102509.

Hepatocyte nuclear factor 3-gamma (350 aa, 37 kDa) is encoded by the human FOXA3 gene. This protein plays a role in the positive regulation of transcription. 